\title{
The comparison of amniotic fluid nuclear factor-kappa B levels in pregnant women who underwent cesarean section or normal vaginal labor
}

\author{
Suat Süphan Erşahin \\ Department of Obstetrics and Gynecology, Faculty of Medicine, Altınbaş University, İstanbul, Turkey
}

\begin{abstract}
Objective: Inflammatory changes in the amniotic membranes during prenatal period have a critical important in the rupture of membranes and the onset of labor. The inflammatory changes in the membranes caused by normal vaginal labors and cesarean sections $(\mathrm{C} / \mathrm{S})$ are different than each other. Nuclear factor-kappa B (Nf- $\kappa \mathrm{B})$ is the basic cellular marker of the inflammation change in biological fluids and tissues. We planned this study to compare amniotic fluid $\mathrm{NF}-\kappa \mathrm{B}(\mathrm{AF}-\mathrm{NF}-\kappa \mathrm{B})$ concentrations in normal vaginal labor cases and those who underwent non-emergency $\mathrm{C} / \mathrm{S}$.

Methods: One-hundred singleton term pregnant women who did not have any serious fetal and maternal problems were included in the study. The pregnant women were separated into two groups, which contained 50 cases each. The week of gestation was calculated according to the last menstrual period and ultrasonography measurements. The groups included 50 patients who did not have the history of clinical chorioamnionitis and preterm premature rupture of membranes and were decided to have normal vaginal labor, and 50 term pregnant women who were decided to have cesarean section due to maternal or perinatal reasons. The amniotic fluid samples were collected during cesarean section or normal vaginal labor. After opening the membranes by scalpel in $\mathrm{C} / \mathrm{S}$ cases and following spontaneous or artificial membrane rupture in vaginal labor cases, the amniotic fluid samples were collected. AF-NF- $\mathrm{KB}$ concentrations were evaluated by ELISA method.

Results: AF-NF- $\kappa \mathrm{B}$ levels of the patients in the group of normal vaginal labor were significantly higher than $\mathrm{AF}-\mathrm{NF}-\mathrm{\kappa B}$ levels of the patients in $\mathrm{C} / \mathrm{S}$ group. AF-NF- $\mathrm{KB}$ levels were about 2 times higher in the group of normal vaginal labor $(1.44 \pm 0.40 \mathrm{ng} / \mathrm{mL}$ vs. $0.71 \pm 2.60$ $\mathrm{ng} / \mathrm{mL}, \mathrm{p}<0.001)$. There was a positive but insignificant correlation between the fetal birth weight and AF-NF-кB levels in the patients who underwent normal vaginal labor. There was no significant correlation between $\mathrm{AF}-\mathrm{NF}-\mathrm{\kappa B}$ levels and demographic and clinical characteristics of the patients who underwent labor by $\mathrm{C} / \mathrm{S}$.

Conclusion: Normal vaginal labor is associated with the increased $\mathrm{AF}$ $\mathrm{NF}-\kappa \mathrm{B}$ concentrations compared to $\mathrm{C} / \mathrm{S}$ cases. $\mathrm{AF}-\mathrm{NF}-\kappa \mathrm{B}$ levels seem to be a potential predictor for the spontaneous fetal membrane rupture.

Keywords: Amniotic fluid, NF-кB, normal vaginal labor, cesarean section.
\end{abstract}

Özet: Sezaryen veya normal vajinal doğum yapan gebelerde amniyotik sıvı nükleer faktör-kappa B düzeylerinin karşılaştırılması

Amaç: Doğum öncesi dönemde amniyotik membranlarda meydana gelen inflamatuvar değişiklikler zarların yırtılmasında ve doğum eyleminin başlamasında kritik bir öneme sahiptir. Normal vajinal doğumlar ile sezaryen (C/S) doğumların zarlarda yaptığı inflamatuvar değişiklikler birbirinden farklıdır. Nükleer faktör-kappa $\mathrm{B}(\mathrm{NF}-\kappa \mathrm{B})$ biyolojik sıvı ve dokularda inflamasyon değișiminin temel hücresel belirtecidir. Bu çalışma normal vajinal doğum olguları ile acil olmayan $\mathrm{C} / \mathrm{S}$ doğum yapan olguların amniyotik sıvı $\mathrm{NF}-\kappa \mathrm{B}(\mathrm{AF}-\mathrm{NF}-\kappa \mathrm{B})$ konsantrasyonlarını karşılaştırmak için planlanmıştır.

Yöntem: Ciddi fetal ve maternal problemi olmayan 100 tekil term gebelik olgusu çalışmaya dahil edildi. Gebeler her grupta 50 hasta olmak üzere iki gruba ayrıldı. Gebelik haftası son adet tarihi ve ultrasonografi ölçümlerine göre hesaplandı. Gruplar klinik koryoamniyonit ve erken membran rüptürü öyküsü olmayan ve normal vajinal doğum kararı verilen 50 hasta ve maternal veya perinatal nedenlerle sezaryen kararı verilen 50 term gebeden oluşmakta idi. Sezaryen veya normal vajinal doğum sırasında amniyotik sıvı örnekleri alındı. C/S olgularında zarların bistüri ile açılmasını takiben, vajinal doğum olgularında ise spontan veya artifisyel zar yırtılmasını takiben amniyotik sıvı örnekleri alındı. AF-NF-кB konsantrasyonları ELISA yöntemi ile değerlendirildi.

Bulgular: Normal vajinal doğum yapılan gruptaki hastaların AF-

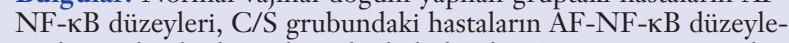
rinden anlamlı düzeyde yüksek bulundu. $\mathrm{AF}-\mathrm{NF}-\kappa \mathrm{B}$ seviyeleri normal vajinal doğum grubunda yaklaşık 2 kat daha yüksekti $(1.44 \pm 0.40 \mathrm{ng} / \mathrm{mL}$ 'ye karş1 $0.71 \pm 2.60 \mathrm{ng} / \mathrm{mL}, \mathrm{p}<0.001)$. Normal vajinal doğum yapan hastalarda fetal doğum ağırlığı ile $\mathrm{AF}-\mathrm{NF}-\kappa \mathrm{B}$ seviyeleri arasında pozitif ancak anlamsız bir korelasyon saptandı. $\mathrm{C} / \mathrm{S}$ ile doğum yapan hastaların $\mathrm{AF}-\mathrm{NF}-\kappa \mathrm{B}$ düzeyleri ile demografik ve klinik özellikleri arasında anlamlı bir ilişki saptanmadı.

Sonuç: Normal vajinal doğum C/S olgularına göre artmış AFNF- $\kappa$ B konsantrasyonları ile ilişkilidir. $A F-N F-\kappa B$ düzeyleri spontan fetal membran rüptürünün potansiyel bir prediktörü gibi görünmektedir.

Anahtar sözcükler: Amniyotik sıvı, NF-кB, normal vajinal doğum, sezaryen.

Correspondence: Suat Süphan Erşahin, MD. Department of Obstetrics and Gynecology, Faculty of Medicine, Altınbaş University, İstanbul, Turkey. e-mail: suphanersahin@hotmail.com / Received: November 9, 2020; Accepted: January 4, 2021

How to cite this article: Erşahin SS. The comparison of amniotic fluid nuclear factor-kappa B levels in pregnant women who underwent cesarean section or normal vaginal labor. Perinatal Journal 2021;29(1):8-12. doi:10.2399/prn.21.0291002 


\section{Introduction}

The correlation between inflammation and nuclear factor-kappa B (NF-kB) has led us to change our knowledge on how physiological process works. NF$\kappa \mathrm{B}$ is a molecule which exists in all cells and biological fluids in physiological amounts and is the major marker of cellular inflammation. Its presence in amniotic fluid is a known fact. NF- $\mathrm{KB}$ is a molecule consisting of homodimers and heterodimers, and it has five subunits. The sub-units are p50/p105 (NF-kB1), p52/p100 (NF-кB2), p65 (RelA), c-Rel, and RelB..$^{[1,2]}$ The activation of any sub-unit by local or systemic stimuli activates the transcription of many inflammatory genes. NF- $\mathrm{BB}$ dimers are located in cell cytoplasm in a way attached to kappa $\mathrm{B}$ protein a (IкBa) inhibitor which blocks nuclear translocation of $N F-\kappa B$. Following the extracellular signals or inflammatory stimulus, NF-кB1 (p105) gets into the nucleus and transforms into $\mathrm{p} 50$ by binding to DNA. This binding causes IкBa phosphorylation and enables $N F-\kappa B^{[2-4]}$ release. The released dimers bind to DNA, reach the nucleus and activate various inflammatory pathways. ${ }^{[5,6]}$

The inflammatory changes in amniotic membranes during prenatal period have a critical importance in the rupture of membranes and the onset of labor. The basic enzymes which have a role in the rupture of amniotic membranes are metalloproteinase urokinase type plasminogen activator and tissue plasminogen activator. $^{[7,8]}$ The relationship between these enzymes and NF- $\kappa \mathrm{B}$ levels are shown in other systems. ${ }^{[1-4]}$ On the other hand, no study was found in the literature addressed on the changes of amniotic fluid NF- $\mathrm{NB}$ $(\mathrm{AF}-\mathrm{NF}-\mathrm{\kappa B})$ levels in normal labor and cesarean section labor cases. ${ }^{[9,10]}$ The differences caused by normal labor and C/S labor on amniotic fluids and membranes are different from each other. For the onset of normal labor, both enzymatic degradations and inflammatory reactions should increase in the amniotic membranes. ${ }^{[10]}$ On the other hand, the changes occurring in amniotic fluids and membranes would be less distinct as most of the C/S procedures are carried out before the onset of labor.

Inflammatory reactions developing in the amniotic membranes are the basic mechanisms for cervical dilation, the rupture of membrane and the onset of labor. The inflammatory changes on the membranes caused by normal vaginal labors and C/S labors are different from each other. NF- $\kappa \mathrm{B}$ is the basic cellular marker of inflammation change in biological fluids and tissues. We planned this study to compare AF-NF- $\mathrm{KB}$ concentrations in normal vaginal labor cases and those who underwent non-emergency $\mathrm{C} / \mathrm{S}$. This would be the first study investigating the differences between normal labors and C/S labors caused by inflammatory reactions in the amniotic fluids.

\section{Methods}

Fifty patients who did not have the history of clinical chorioamnionitis and preterm premature rupture of membranes (PPROM) and were decided to have normal vaginal labor, and 50 term pregnant women who were decided to have cesarean section due to maternal or perinatal reasons were included in the study. All patients included in the study were chosen from those with singleton pregnancy. Multiple pregnancy cases were excluded from the study. Gestational age was determined by using two different methods, which were the last menstrual period and prenatal ultrasound examination at the first 14 weeks of gestation. The cases with PPROM history, emergency $\mathrm{C} / \mathrm{S}$ cases, the patients with placenta previa or ablatio placentae, the patients with the history of diabetes mellitus or gestational diabetes mellitus and those decided to have $\mathrm{C} / \mathrm{S}$ due to preeclampsia and eclampsia were excluded from the study. The patients with the history of systemic inflammatory disease or recurrent urinary infection were also excluded from the study. The cases who were decided to have normal vaginal labor but switched to $\mathrm{C} / \mathrm{S}$ due to obstetric or perinatal reasons were excluded from the study as well. In normal vaginal labor cases, amniotic fluid samples were collected following spontaneous membrane rupture or artificial membrane rupture. The membranes were ruptured artificially in most of the cases in order to standardize sample collecting. The patients who had spontaneous membrane rupture at home and applied to hospital for labor were excluded from the study. In most of the normal vaginal labor cases, cervical dilation occurred at 5-6 cm, and the effacement recorded was about $70-80 \%$. In the breech presentation cases, cervical canal changes were not included in the study as they were different than cephalic presentation. In $\mathrm{C} / \mathrm{S}$ cases, amniotic fluid samples were collected after fetal membranes were incised and before fetal part was removed by hand. It was paid attention not to contaminate the sam- 
ples by blood. The samples containing high levels of blood and vernix caseosa were not included in the study. The samples containing middle levels of blood and vernix caseosa were included in the study after centrifuging them.

\section{NF-kB1 (p105) analysis in the amniotic fluid by ELISA method}

Amniotic fluid NF- $\mathrm{KB} 1$ (p105) sub-unit concentrations were measured by enzyme-linked immunosorbent assay (ELISA) in all cases of normal labor and C/S. This immunological test kit (USCN Life Sci Inc, Wuhan, China) is used for the in vitro quantitative assay of human NF-кB1 (p105) concentrations in serum, plasma, urine, tissue homogenates and other biological fluids. Amniotic fluid sample was treated by phosphate buffered saline to remove vernix caseosa and blood. Then AF samples were kept $-20^{\circ} \mathrm{C}$ until analysis after centrifuging them at $3000 \mathrm{rpm}$ for 5 minutes. $\mathrm{AF}-\mathrm{NF}-\kappa \mathrm{B}$ levels were analyzed according to the method specified in the kit. The detection range of the kit is between 0.312 and $20 \mathrm{ng} / \mathrm{mL}$. The intra-assay and inter-assay variation coefficients for AF-NF- $\mathrm{\kappa B} 1$ (p105) were found $<10 \%$ and $<12 \%$, respectively. The results were presented as $\mathrm{ng} / \mathrm{mL}$.

\section{Statistical analysis}

SPSS Statistics 21.0 (SPSS Inc., Chicago, IL, USA) was used for the statistical analysis. The data were tested by Kolmogorov-Smirnov test to check if they had normal distribution, and all variables were found to be normal. While constant variables were analyzed by post-hoc Tukey procedure, variance analysis test and MannWhitney $U$ test while the categorical data were analyzed by Pearson chi-square test. Pearson's correlation analysis was used to determine the correlation between $\mathrm{AF}$ $\mathrm{NF}-\kappa \mathrm{B}$ levels and other parameters. The value of $\mathrm{p}<.05$ was considered as the significance level. The results were presented as mean $\pm \mathrm{SD}$.

\section{Results}

The demographic and laboratory characteristics of the patients who delivered by normal vaginal labor or $\mathrm{C} / \mathrm{S}$ are shown in the Table 1 . There was no difference between the groups in terms of age, week of gestation, fetal birth weight, gravida and parity. AF-NF- $\mathrm{BB}$ levels of the patients in the group of normal vaginal labor were found significantly higher than AF-NF- $\mathrm{BB}$ levels of the patients in the $\mathrm{C} / \mathrm{S}$ group $(\mathrm{p}<0.001)$. $\mathrm{AF}-\mathrm{NF}-\kappa \mathrm{B}$ levels were approximately 2 times higher in the group of normal vaginal labor than the patients in the $\mathrm{C} / \mathrm{S}$ group $(1.44 \pm 0.40 \mathrm{ng} / \mathrm{mL}$ vs. $0.71 \pm 2.60 \mathrm{ng} / \mathrm{mL}, \mathrm{p}<0.001)$. A positive correlation was found between fetal birth weight and $\mathrm{AF}-\mathrm{NF}-\kappa \mathrm{B}$ levels in the group of normal vaginal labor. However, this correlation had a low $r$ value and was not statistically significant $(\mathrm{r}=0.34, \mathrm{p}<0.40)$. Similarly, there was no significant correlation between AF-NF- $\kappa B$ levels and maternal and fetal parameters in the $\mathrm{C} / \mathrm{S}$ group.

\section{Discussion}

The mechanisms initializing labor in human have been unclear. However, there is a known fact that the labor is a process that multiple systems work in a coordinated way. The collective actions of mother, fetus and its components merge in a single pathway, which is called inflammatory pathway. A distinct increase occur in the synthesis and release of placental corticotropin releasing hormone towards the end of pregnancy. This increase stimulates the synthesis of many inflammatory molecules, and prostaglandins in particular. The activation of inflammatory reactions stimulates MMPs, uPA and tPA enzymes which exist in the fetal membranes intensively,

Table 1. Demographic and laboratory characteristics of the patients who delivered by normal vaginal labor and cesarean section (C/S).

\begin{tabular}{|c|c|c|c|}
\hline & Normal vaginal labor $(n=50)$ & Labor by $C / S(n=50)$ & p-value \\
\hline Age (year) & $29.13 \pm 0.33$ & $28.02 \pm 1.09$ & 0.33 \\
\hline Gravida & $3.17 \pm 0.40$ & $2.23 \pm 0.40$ & 0.13 \\
\hline Parity & $2.30 \pm 9.43$ & $1.77 \pm 0.40$ & 0.09 \\
\hline Week of gestation & $37.60 \pm 9.77$ & $37.11 \pm 9.42$ & 0.54 \\
\hline Fetal weight (gram) & $2987.12 \pm 123.1$ & $2885.34 \pm 233.4$ & 0.59 \\
\hline AF-NF-кB (ng/mL) & $1.44 \pm 0.40$ & $0.71 \pm 2.60$ & 0.001 \\
\hline
\end{tabular}


resulting in the weakening and the rupture of fetal membranes. ${ }^{[7,8]} \mathrm{NF}-\mathrm{\kappa B}$, which is in the cell cytoplasm during prenatal period in an inhibited state, is activated by hormonal and local stimulations which initiate the labor. ${ }^{[1-4]}$ The cytokines, prostaglandins, nitric oxide and steroid hormones which intensify in fetal membranes and amniotic fluid during the prenatal period are the basic stimuli increasing the local synthesis of NF- $\mathrm{KB}$ in fetal membranes. ${ }^{[1]]}$ The increase of cytokines in fetal membranes and amniotic fluid stimulates $\mathrm{NF}-\kappa \mathrm{B}$ and enables it to get into nucleus. ${ }^{[4]}$ After reaching nucleus, NF- $\kappa \mathrm{B}$ causes the activation of many target genes and inflammation peak via some proteins. The common and final result of all these reactions is the rupture of fetal membranes. In our study, we found that the AF-NF-кB levels of the normal labor cases were two times higher than the $\mathrm{AF}$ $\mathrm{NF}-\kappa \mathrm{B}$ levels of the $\mathrm{C} / \mathrm{S}$ cases. The reason for the lower $\mathrm{NF}-\kappa \mathrm{B}$ levels in $\mathrm{C} / \mathrm{S}$ group than the normal vaginal labor group may be their non-exposure to the active labor. This information makes us strongly think that the labor should start in order for the inflammatory process to start in fetal membranes and amniotic fluid.

We clearly showed in our study that NF-кB levels, which is the basic inflammatory marker, are significantly higher in the amniotic fluid of the cases who underwent normal vaginal labor than those of $\mathrm{C} / \mathrm{S}$ cases. This elevation in NF- $\mathrm{KB}$ levels is the clear sign showing that normal labor occurred as a result of an inflammatory process. Non-presence of any correlation between $\mathrm{AF}$ $\mathrm{NF}-\kappa \mathrm{B}$ levels and obstetric and demographic parameters indicates that NF- $\kappa \mathrm{B}$ synthesis and release have a unique and independent functionality.

We do not know when the intensive increase seen in AF-NF- $\kappa \mathrm{B}$ levels starts and what is the basic triggering mechanism. The increase in the synthesis and release of cytokines, prostaglandins, nitric oxide and sex steroids before labor can be the beginning of extracellular matrix and collagen degradation. ${ }^{[7,8,1]}$ These enzymes trigger the synthesis and release of NF- $\mathrm{KB}$ both in fetal membranes and amniotic fluid. At physiological level, local infection and microbiota invasion also causes chorioamnionitis and stimulates NF- $\mathrm{NB}$ synthesis. ${ }^{[2-4]} \mathrm{NF}-\kappa \mathrm{B}$ leads to the rupture of membranes and the onset of labor by reaching critical threshold in the fetal components and amniotic fluid. ${ }^{[5,6]}$

One of the major limitations of the study is the exclusion of the cases who switched to $\mathrm{C} / \mathrm{S}$ due to obstetric or perinatal reasons although they were planned to have normal vaginal labor. In fact, if it was possible to evaluate these cases as a separate group, the correlation between $\mathrm{AF}-\mathrm{NF}-\kappa \mathrm{B}$ levels and the duration spent during labor could be presented. Studies assessing such patients who had to switch to $\mathrm{C} / \mathrm{S}$ are needed in order to determine the impact of enzymatic changes and inflammatory conditions occurring in cervix and membranes during labor on NF- $\mathrm{KB}$ levels. In this way, it can be revealed if the change in NF- $\mathrm{KB}$ levels is associated with labor or not.

If $\mathrm{NF}-\kappa \mathrm{B}$ expression levels are responsible for the rupture of amniotic membranes in term labors, the same mechanism may also be responsible for preterm labor and premature rupture of membranes. Chorioamnionitis is one of the major underlying reasons for both preterm labor and premature rupture of membranes. The infections of decidua and amnio-chorionic membranes stimulate NF- $\mathrm{\kappa B}$ expression and may lead to the inflammation and then rupture of membranes. The rupture of membrane may be associated with the injury of collagen structure due to increased inflammatory cytokines, and cytokines may cause preterm labor or premature rupture of membranes by blocking progesterone receptors and stimulating prostaglandin synthesis. There is no study investigating $\mathrm{AF}-\mathrm{NF}-\kappa \mathrm{B}$ levels in PPROM cases. If it can be confirmed that AF-NF- $\kappa B$ levels increase in the cases of preterm labor and premature rupture of membranes, it may enable new options to be included in our clinical practice for the follow-up and treatment procedures of the cases. There may be opportunities to use $\mathrm{NF}-\kappa \mathrm{B}$ inhibitors in the preterm labor and premature rupture of membranes for that purpose.

\section{Conclusion}

In our study, we confirmed the hypothesis asserting that the inflammatory pathways work more actively in the cases of normal vaginal labor compared to $\mathrm{C} / \mathrm{S}$ cases and initiate labor by enabling the spontaneous rupture of fetal membranes by scientific data. Conducting studies which investigate the relationships between NF- $\mathrm{KB}$ levels and post-term pregnancies and PPROM cases would help to understand the role of NF-кB in human labor better. Making the relationship between NF- $\kappa \mathrm{B}$ pathway and labor clearer would provide following opportunities for obstetricians: (i) the use of NF- $\mathrm{KB}$ activators in the management of post-term pregnancies, (ii) preventing early activation of $\mathrm{NF}-\kappa \mathrm{B}$ pathway, (iii) addressing 
the use of NF- $\kappa \mathrm{B}$ analogues for the induction of pregnancies. In conclusion, more comprehensive studies are required to use $\mathrm{AF}-\mathrm{NF}-\kappa \mathrm{B}$ levels routinely in normal labors, C/S, PPROM and complicated pregnancies.

Funding: This work did not receive any specific grant from funding agencies in the public, commercial, or not-for-profit sectors.

Compliance with Ethical Standards: The author stated that the standards regarding research and publication ethics, the Personal Data Protection Law and the copyright regulations applicable to intellectual and artistic works are complied with and there is no conflict of interest.

\section{References}

1. Beinke S, Ley SC. Functions of NF-kappaB1 and NFkappaB2 in immune cell biology. Biochem J 2004;382:393409. [PubMed] [CrossRef]

2. Chen LF, Greene WC. Shaping the nuclear action of NFkappaB. Nat Rev Mol Cell Biol 2004;5:392-401. [PubMed] [CrossRef]

3. Pahl HL. Activators and target genes of Rel/NF-kappaB transcription factors. Oncogene 1999;18:6853-66. [PubMed] [CrossRef]
4. Renard P, Raes M. The proinflammatory transcription factor NFkappaB: a potential target for novel therapeutical strategies. Cell Biol Toxicol 1999;15:341-4. [PubMed] [CrossRef]

5. Karin M, Yamamoto Y, Wang QM. The IKK NF-kappa B system: a treasure trove for drug development. Nat Rev Drug Discov 2004;3:17-26. [PubMed] [CrossRef]

6. Hoffimann A, Baltimore D. Circuitry of nuclear factor kappa B signaling. Immunol Rev 2006;210:171-86. [PubMed] [CrossRef]

7. Novak U, Cocks BG, Hamilton JA. A labile repressor acts through the NFkB-like binding sites of the human urokinase gene. Nucleic Acids Res 1991;19:3389-93. [PubMed] [CrossRef]

8. Aggarwal BB. Nuclear factor-kappa B: the enemy within. Cancer Cell 2004;6:203-8. [PubMed] [CrossRef]

9. Arpaci H, Yapca OE. Amniotic fluid NF-kB concentration in pregnant women with a high risk of prenatal screening test results. Ginekol Pol 2018;89:577-80. [PubMed] [CrossRef]

10. Bredeson S, Papaconstantinou J, Deford JH, Kechichian T, Syed TA, Saade GR, et al. HMGB1 promotes a 38 MAPK associated non-infectious inflammatory response pathway in human fetal membranes. PLoS One 2014;9:e113799. [PubMed] [CrossRef]

11. Ribeiro ML, Farina M, Aisemberg J, Franchi A. Effects of in vivo administration of epidermal growth factor (EGF) on uterine contractility, prostaglandin production and timing of parturition in rats. Reproduction 2003;126:459-68. [PubMed] [CrossRef]

This work is licensed under the Creative Commons Attribution-NonCommercial-NoDerivs 4.0 Unported (CC BY-NC-ND4.0) License. To view a copy of this license, visit http://creativecommons.org/licenses/by-nc-nd/4.0/ or send a letter to Creative Commons, PO Box 1866, Mountain View, CA 94042, USA.

Publisher's Note: The content of this publication does not necessarily reflect the views or policies of the publisher, nor does any mention of trade names, commercial products, or organizations imply endorsement by the publisher. Scientific and legal responsibilities of published manuscript belong to their author(s). The publisher remains neutral with regard to jurisdictional claims in published maps and institutional affiliations. 